\title{
Klasifikasi Kinerja Karyawan Terhadap Penjualan Produk Menggunakan Metode Regresi Logistik dan Nä̈ve Bayes (Studi Kasus PT. Gunung Meranti, Kalimantan Selatan)
}

\author{
${ }^{(1)}$ Nursya'bani Hendro Prabowo dan ${ }^{(2)}$ Irhamah \\ Departemen Statistika, Fakultas Matematika, Komputasi dan Sains Data, \\ Institut Teknologi Sepuluh Nopember \\ Jl. Arief Rahman Hakim, Surabaya 60111 Indonesia \\ e-mail: ${ }^{(1)}$ nrsyabanihendra@gmail.com, ${ }^{(2)}$ irhamah@ @statistika.its.ac.id
}

\begin{abstract}
Abstrak-PT. Gunung Meranti merupakan perusahaan perseroan tertutup yang terletak di Kalimantan Selatan.Perusahaan bergerak di bidang industri perhutanan dan agro-tani.Produk perusahaan terdiri dari kayu bulat dan kayu lapis dengan volume meter kubik, serta produksi agro-tani seperti perkebunan kopi,jeruk dan pertanian padi. Produk perusahaan dengan ragam tersebut memerlukan pemasaran yang cukup strategis dan intensitas kerja yang lebih tinggi, hal ini dikarenakan konsumen dari perusahaan bukan merupakan end user seperti industri rumah tangga ataupun individu, melainkan perusahaan seperti perusahaan konstruksi, properti dan perusahaan pengembangan yang berskala besar. Tingkat intensitas kerja yang tinggi tersebut menyebabkan perusahaan perlu melakukan analisa terhadap performa dari karyawan untuk menentukan target bagi masing-masing karyawan, serta melakukan penilaian terhadap kinerja masing-masing individu dalam hal gaji pokok maupun bonus.Perbandingan ketepatan klasifikasi dan kebaikan model menunjukkan bahwa Regresi Logistik dan Nä̈ve Bayes menghasilkan model yang sama baiknya dengan skema terbaik adalah data training $70 \%$ dan data testing 30\%. Perbandingan jika dilihat menggunakan RMSE cenderung menunjukkan Nä̈ve Bayes dengan skema $70 \%$ merupakan model yang disarankan dengan RMSE yang cenderung rendah dibanding skema dan metode lain.
\end{abstract}

Kata Kunci-Regresi Logistik, Nä̈ve Bayes, Kinerja Karyawan, Ketepatan klasifikasi.

\section{PENDAHULUAN}

$\mathrm{P}$ erusahaan yang berbasis industri secara garis besar menitikberatkan penjualan produk mereka sebagai basis perusahaan tersebut bertahan dan berekspansi. Persaingan produk dan ragam produk antar perusahaan mempengaruhi penjualan produk suatu perusahaan sehingga ada kemungkinan persaingan tersebut membuat keuntungan atau kerugian.Penjualan produk suatu perusahaan terletak di bidang pemasarannya, yang diisi oleh karyawan dengan kemampuan bidang pemasaran atau publik relasi.Letak penjualan produk di bidang tersebut menjadikan kinerja karyawan untuk memasarkan produk menjadi penting dan perlu dikaji performansinya.

PT. Gunung Meranti merupakan perusahaan perseroan tertutup yang terletak di Kalimantan Selatan.Perusahaan bergerak di bidang industri perhutanan dan agro-tani.Produk perusahaan terdiri dari kayu bulat dan kayu lapis dengan volume meter kubik, serta produksi agro-tani seperti perkebunan kopi, jeruk dan pertanian padi. Produk perusahaan dengan ragam tersebut memerlukan pemasaran yang cukup strategis dan intensitas kerja yang lebih tinggi, hal ini dikarenakan konsumen dari perusahaan bukan merupakan end user seperti industri rumah tangga ataupun individu, melainkan perusahaan seperti perusahaan konstruksi, properti dan perusahaan pengembangan yang berskala besar.

Tingkat intensitas kerja yang tinggi tersebut menyebabkan perusahaan perlu melakukan analisa terhadap performa dari karyawan untuk menentukan target bagi masing-masing karyawan, serta melakukan penilaian terhadap kinerja masingmasing individu dalam hal gaji pokok maupun bonus. Langkah yang dapat dilakukan salah satunya adalah melakukan klasifikasi terhadap kinerja karyawan berdasarkan penjualan produk perusahaan.Kinerja karyawan yang dilihat perusahaan adalah ketanggapan karyawan atau disebut daya tanggap, kreatifitas dari karyawan dalam penjualan produk serta motivasi atau semangat dari karyawan. Klasifikasi akan dilakukan menggunakan metode Regresi Logistik dan Nä̈ve Bayes. Penggunaan regresi logistik dilakukan karena kepuasan tidak dapat diukur secara langsung, melainkan melalui beberapa dimensi, kemudian di-break down menjadi beberapa indikator [1]. Klasifikasi dengan regresi logistik dilakukan dengan mentransformasi variable dependen ke variable logit yang merupakan natural log dari odds ratio. Penggunaan kedua metode tersebut akan menghasilkan model terbaik yang dapat dianjurkan untuk PT. Gunung Meranti sebaga model klasifikasi kinerja karyawan dengan harapan perusahaan memberikan hak dan kewajiban yang sesuai untuk masing-masing karywan.

\section{TINJAUAN PUSTAKA}

\section{A. Metode Regresi Logistik}

Regresi logistik digunakan jika variabel respon bersifat kategorik (nominal atau ordinal) dengan variabel-variabel predictor kontinu maupun kategorik [2]. Variabel respon y yang bersifat random dan dikotomus, yakni bernilai 1 denga probabilitas $\pi$ dan bernilai 0 dengan probabilitas $1-\pi$, disebut sebagai point binomial Variabel respon dengan notasi y dan variabel prediktor dengan notasi $\mathrm{x}$, jika variabel respon menghasilkan dua kemungkinan kategori, make variabel tersebut mengikuti distribusi Bernoulli. Secara umum, model regresi logistik yang dinyatakan sebagai fungsi $\mathrm{x}$ adalah [3]:

$$
\pi(\mathrm{x})=\frac{\exp \left(\beta_{0}+\beta_{1} x\right)}{1+\exp \left(\beta_{0}+\beta_{1} x\right)}
$$

Untuk mempermudah penaksiran parameter regresi, maka digunakan transformasi logit terhadap $\pi(\mathrm{x})$ sehingga menjadi bentuk logit pada persamaan berikut. 


$$
g(\mathrm{x})=\ln \left(\frac{\pi(x)}{1-\pi(x)}\right)=\beta_{0}+\beta_{1} x
$$

Metode maximum likelihood (metode kemungkinan maksimum) digunakan untuk menduga parameter-parameter dari model regresi logistic $\beta^{1}=\left[\begin{array}{lllll}\beta_{0} & \beta_{1} & \ldots & \beta_{\mathrm{k}}\end{array}\right]$ maka pada dasarnya metode maximum likelihood mengestimasi nilai $\boldsymbol{\beta}$ dengan memaksimumkan fungsi Likelihood $^{(2)}$.

Maksimum ln likelihood dapat diperoleh dengan cara mendiferensialkan $L(\beta)$ terhadap $\beta$ dan menyamakannya dengan nol $^{(1)}$. Kemudian diferensialkan lagi terhadap masingmasing elemen $\beta$. Sedangkan metode untuk mengestimasi varian dan kovarians dari estimasi koefisien parameter dikembangkan teori maximum likelihood estimation.Teori ini menyatakan bahwa estimasi varian diperoleh dari turunan kedua fungsi likelihood.

Hasil dari prosedur klasifikasi akan ditampilkan dalam bentuk matriks sebagai berikut.

\begin{tabular}{|c|c|c|}
\hline \multirow{2}{*}{ Tabel 1. Matriks klasifikasi } \\
\cline { 2 - 3 } & \multicolumn{2}{|c|}{ Prediksi } \\
\cline { 2 - 3 } & Rendah & Tinggi \\
\hline Rendah & TN & FP \\
\hline Tinggi & FN & TP \\
\hline
\end{tabular}

Persentase ketepatan pengelompokan dapat dihitung dari matriks klasifikasi yang tepat menempatkan hasil prediksi terhadap data aktual dari setiap kelompok.Setelah diperoleh klasifikasi untuk masing-masing observasi, nilai dapat dihitung.Ketepatan klasifikasi merupakan suatu ukuran yang menentukan apakah klasifikasi yang telah dilakukan akurat atau tidak.

\section{B. Nä̈ve Bayes Classification}

Nä̈ve Bayes merupakan salah satu teknik data mining berupa algoritma yang menerapkan teori Bayes dalam klasifikasi.Keputusan Bayes merupakan Teorema yang bersifat pendekatan statistic fundamental dalam pengenalan pola.Nä̈ve Bayes memiliki dasaran pada asumsi penyederhanaan bahwa nilai atribut secara kondisional saling bebas jika diberikan nilai output.Jika diberikan nilai output maka probabilitas mengamati secara bersama adalah produk dari probabilitas individu.

Penggunaan Persamaan 1 ke Persamaan 2 akan memperoleh pendekatan yang digunakan dalam Nä̈ve Bayes Classification.

$$
\begin{aligned}
& P\left(a_{1}, a_{2}, a_{3}, \ldots, a_{n} \mid V_{j}\right)=\prod P\left(a_{i} \mid v_{j}\right) \\
& V_{N B}=\arg \max _{\mathrm{vj} \in \mathrm{V}} P\left(V_{j}\right) \prod P\left(a_{i} \mid v_{j}\right)
\end{aligned}
$$

\section{Dengan \\ $V_{N B} \quad$ : Nilai output hasil klasifikasi Nä̈ve Bayes \\ $P\left(a_{i} \mid v_{j}\right)$ : Rasio antara $\mathrm{n}_{\mathrm{c}}, \mathrm{n}$, dimana $\mathrm{n}_{\mathrm{c}}$ adalah jumlah data training untuk $\mathrm{v}=\mathrm{v}_{\mathrm{j}}$ dan $\mathrm{a}=\mathrm{a}_{\mathrm{i}}$; dan $\mathrm{n}$ adalah total kemungkinan output.}

\section{METODOLOGI PENELITIAN}

\section{A. Sumber data}

Data yang digunakan dalam analisis ini yaitu data sekunder pengamatan kinerja karyawan bidang departemen pemasaran PT. Gunung Meranti.Data ini diambil pada bulan Januari 2016 hingga Desember 2016.

\section{B. Variabel Penelitian}

Variabel-variabel penelitian yang digunakan dalam penelitian iniantara lainsebagai berikut.

Y : Tingkat Penjualan Produk dari Karyawan ( 0 = rendah, 1 = tinggi)

$\mathrm{X}_{1}$ : Daya Tanggap dari Karyawan $(0=$ rendah, $1=$ sedang, 2 = tinggi $)$

$\mathrm{X}_{2}$ : Kreatifitas dari Karyawan $(0=$ rendah, 1 = sedang, 2 = tinggi $)$

$\mathrm{X}_{3}$ : Motivasi dari Karyawan $(0$ = rendah, 1 = sedang, 2 = tinggi $)$

\section{Langkah Analisis}

Langkah analisis pada penelitian ini antara lain.

1. Menentukan variabel-variabel penelitian

2. Mengambil data

3. Mengentri data

4. Melakukan pengolahan data dengan regresi 84 ogisticdan Nä̈ve Bayes.

5. Membandingkan hasil analisis antara metode regresi 84ogistic dan Nä̈ve Bayes berdasarkan nilai persentase ketepatan klasifikasinya.

6. Menarik kesimpulan dan membuat saran untuk penelitian selanjutnya.

\section{ANALISIS DAN PEMBAHASAN}

\section{A. Karakteristik Kinerja Karyawan PT. Gunung Meranti}

Karakteristik dari karyawan departemen pemasaran PT. Gunung Meranti akan disajikan menggunakan pie chart yang berisi informasi mengenai kategori karyawan.

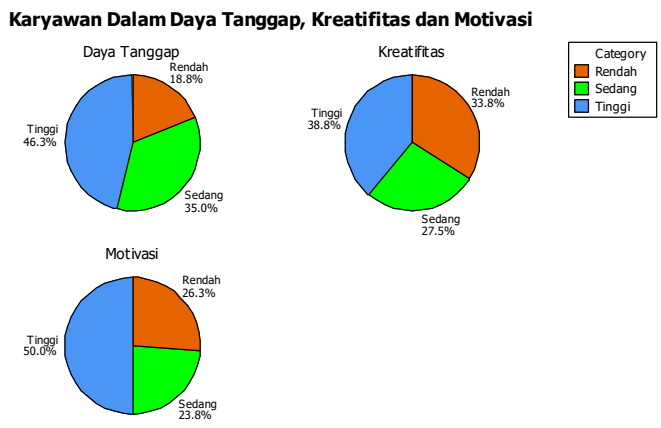

Gambar 1. Karakteristik Karyawan PT. Gunung Meranti

Gambar 1 menunjukkan bahwa karyawan departemen pemasaran PT. Gunung Meranti memiliki kategori daya tanggap tinggi sebanyak 37 orang, 28 orang memiliki daya tanggap rata-rata sedangkan 15 orang sisanya memiliki daya tanggap yang tergolong rendah terhadap instruksi pimpinan atau membaca kondisi perusahaan.

Kreatifitas karyawan PT. Gunung Meranti merupakan salah satu kinerja karyawan yang dinilai oleh HRD dan pimpinan perusahaan.Semakin tinggi kreatifitas karyawan diharapkan mampu memberikan inovasi-inovasi dalam rangka peningkatan penjualan.Dari hasil karakteristik, diketahui bahwa karyawan yang dinilai memiliki inovasi paling tinggi dalam pemasaran sebanyak 31 orang, karyawan yang memiliki inovasi rata-rata sebanyak 22 orang dan karyawan yang jarang memberikan inovasi dalam perusahaan sebanyak 27 orang. 
Semangat karyawan merupakan salah satu aspek yang dilihat perusahaan sebagai aspek yang perlu dikembangkan bersama-sama.Hasil menunjukkan bahwa motivasi atau semangat karyawan terhadap pekerjaannya masih cukup banyak dengan karyawan motivasi tinggi sebanyak 40 orang, karyawan dengan semangat yang tergolong rata-rata sebanyak 19 orang dan sebanyak 21 orang sisanya dinilai memiliki motivasi atau semangat bekerja yang cukup rendah.

\section{B. Klasifikasi Kinerja Karyawan dengan Regresi Logistik}

Klasifikasi akan membagi data menjadi training dan testing dengan skema $90 \%, 80 \%$ dan $70 \%$.

\section{Skema 90\% Data Training dan 10\% Data Testing}

Skema ini akan membagi data training yang digunakan sebanyak 72 data untuk menduga atau data testing sebanyak 8 data. Hasil klasifikasi untuk pembentukan model adalah sebagai berikut.

\begin{tabular}{lrr}
\multicolumn{3}{c}{ Tabel 2. Variabel Menggunakan Skema 90\% } \\
\hline Variabel & Koefisien & Odd Ratio \\
\hline Daya Tanggap Rendah & 66,54 & 7,93 \\
Daya Tanggap Sedang & $-4,22$ & 0,01 \\
Daya Tanggap Tinggi & $-36,91$ & 0 \\
Kreatifitas Rendah & 81,61 & 2,77 \\
Kreatifitas Sedang & $-40,28$ & 0 \\
Kreatifitas Tinggi & $-43,04$ & 0 \\
Motivasi Rendah & 73,31 & 6,89 \\
Motivasi Sedang & $-5,58$ & 0,01 \\
Motivasi Tinggi & $-52,72$ & 0 \\
Intercept & 6,37 & - \\
\hline
\end{tabular}

Tabel menunjukkan bahwa kinerja karyawan yang rendah cenderung sangat mempengaruhi penjualan produk. Karyawan dengan daya tanggap rendah juga patut dilakukan perbaikan karena dampaknya pada penjualan produk akan menurunkan penjualan 7,93 kali lebih rendah. Motivasi atau semangat karyawan yang rendah juga akan membuat penjualan produk menurun 6,89 kali lebih rendah.Hasil klasifikasi terhadap data testing adalah sebagai berikut.

Tabel 3. Klasifikasi Menggunakan Skema 90\%

\begin{tabular}{lrr}
\hline Penjualan Produk & Rendah & Tinggi \\
\hline Rendah & 5 & 0 \\
Tinggi & 1 & 2 \\
\hline
\end{tabular}

Tabel menunjukkan penggunaan regresi logistik untuk klasifikasi menggunakan data testing atau sebanyak 8 data yang diuji.Kebaikan dari klasifikasi tersebut adalah sebagai berikut.

\begin{tabular}{lc} 
Tabel 4. Hasil Ketepatan dan Kebaikan Model Skema 90\% \\
\hline Hasil Klasifikasi & Nilai \\
\hline Correctly Classified Instance & $87,5 \%$ \\
Incorrectly Classified Instance & $12,5 \%$ \\
Kappa Statistics & 0,7143 \\
Root Mean Squared Error & 0,3536 \\
\hline
\end{tabular}

Tabel menunjukkan summary atau rangkuman dari proses klasifikasi. Regresi logistik membentuk model dengan klasifikasi tepat sebesar 87,5\%. Kesalahan klasifikasi sebesar $12,5 \%$ atau RMSE dengan nilai 0,3536. Kesesuaian model diukur menggunakan nilai Kappa Statistics, dari model tersebut diketahui nilai sebesar 0,7143 atau model klasifikasi memiliki kesesuaian yang sudah cukup baik untuk digunakan.

\section{Skema 80\% Data Training dan 20\% Data Testing}

Penggunaan data training untuk skema ini adalah sebanyak 64 data, dan untuk data testing sebanyak 16 data.Hasil klasifikasi untuk pembentukan model memiliki kesamaan dengan penggunaan skema sebelumnya.

Tabel 5. Variabel Menggunakan Skema 80\%

\begin{tabular}{lrr}
\hline Variabel & Koefisien & Odd Ratio \\
\hline Daya Tanggap Rendah & 66,54 & 7,93 \\
Daya Tanggap Sedang & $-4,22$ & 0,01 \\
Daya Tanggap Tinggi & $-36,91$ & 0 \\
Kreatifitas Rendah & 81,61 & 2,77 \\
Kreatifitas Sedang & $-40,28$ & 0 \\
Kreatifitas Tinggi & $-43,04$ & 0 \\
Motivasi Rendah & 73,31 & 6,89 \\
Motivasi Sedang & $-5,58$ & 0,01 \\
Motivasi Tinggi & $-52,72$ & 0 \\
Intercept & 6,37 & - \\
\hline
\end{tabular}

Tabel menunjukkan nilai dan interpretasi yang hampir serupa dengan skema sebelumnya.Hasil klasifikasi terhadap data testing adalah sebagai berikut.

Tabel 6. Klasifikasi Menggunakan Skema 80\%

\begin{tabular}{lrrr}
\hline Penjualan Produk & Rendah & Tinggi & \\
\hline Rendah & 8 & 0 \\
Tinggi & 1 & 7 \\
\hline
\end{tabular}

Karyawan dengan penjualan produk rendah terdapat sebanyak 8 orang dan penjualan produk tinggi terdapat 7 orang. Melihat kebaikan dari klasifikasi tersebut akan menggunakan Tabel berikut.

Tabel 7.

Hasil Ketepatan dan Kebaikan Model Skema 80\%

\begin{tabular}{lr}
\hline Hasil Klasifikasi & Nilai \\
\hline Correctly Classified Instance & $93,75 \%$ \\
Incorrectly Classified Instance & $6,25 \%$ \\
Kappa Statistics & 0,875 \\
Root Mean Squared Error & 0,25 \\
\hline
\end{tabular}

Hasil menunjukkan bahwa klasifikasi memiliki ketepatan sebesar $93,75 \%$ atau meningkat dari skema sebelumnya. Kesalahan klasifikasi adalah sebesar 6,25\% dan RMSE bernilai 0,25 atau mengalami penurunan tingkat kesalahan. Kebaikan model tersebut berdasarkan nilai Kappa Statistics adalah sebesar 0,875 (mendekati nilai 1) atau dikategorikan sangat baik untuk digunakan sebagai model.

\section{Skema 70\% Data Training dan 30\% Data Testing}

Skema terakhir yang digunakan adalah membagi data menjadi 56 data untuk training dan 24 menjadi testing.Hasil klasifikasi untuk pembentukan model masih memiliki kesamaan dengan penggunaan skema sebelumnya.

\begin{tabular}{lrr}
\multicolumn{3}{c}{ Tabel 8. Variabel Menggunakan Skema 70\% } \\
\hline Variabel & Koefisien & Odd Ratio \\
\hline Daya Tanggap Rendah & 66,54 & 7,93 \\
Daya Tanggap Sedang & $-4,22$ & 0,01 \\
Daya Tanggap Tinggi & $-36,91$ & 0 \\
Kreatifitas Rendah & 81,61 & 2,77 \\
Kreatifitas Sedang & $-40,28$ & 0 \\
Kreatifitas Tinggi & $-43,04$ & 0 \\
Motivasi Rendah & 73,31 & 6,89 \\
Motivasi Sedang & $-5,58$ & 0,01 \\
Motivasi Tinggi & $-52,72$ & 0 \\
Intercept & 6,37 & - \\
\hline
\end{tabular}


Tabel masih menunjukkan hasil yang sama dengan pembentukan model sebelumnya. Hasil klasifikasi data testing berdasarkan model tersebut adalah sebagai berikut.

\begin{tabular}{lrr}
\multicolumn{4}{c}{ Tabel 9. Klasifikasi Menggunakan Skema 70\% } \\
\hline Penjualan Produk & Rendah & Tinggi \\
\hline Rendah & 12 & 0 \\
Tinggi & 1 & 11 \\
\hline
\end{tabular}

Hasil klasifikasi tersebut menunjukkan bahwa karyawan dengan penjualan produk rendah sebanyak 12 orang dan karyawan yang tergolong memiliki performa penjualan produk tinggi sebanyak 11 orang. Kebaikan dari klasifikasi model akan dilihat melalu hasil sebagai berikut.

Tabel 10. Hasil Ketepatan dan Kebaikan Model Skema 70\%

\begin{tabular}{lr}
\hline Hasil Klasifikasi & \multicolumn{1}{c}{ Nilai } \\
\hline Correctly Classified Instance & $95,83 \%$ \\
Incorrectly Classified Instance & $4,17 \%$ \\
Kappa Statistics & 0,9167 \\
Root Mean Squared Error & 0,2041 \\
\hline
\end{tabular}

Hasil menunjukkan bahwa klasifikasi memiliki ketepatan sebesar 95,83\% atau meningkat dari skema sebelumnya. Kesalahan klasifikasi adalah sebesar 4,17\% dan RMSE bernilai 0,2041 atau mengalami penurunan tingkat kesalahan. Kebaikan model tersebut berdasarkan nilai Kappa Statistics adalah sebesar 0,9167 (mendekati nilai 1) atau dikategorikan sangat baik untuk digunakan sebagai model.

\section{Klasifikasi Kinerja Karyawan dengan Nä̈ve Bayes}

Metode Naïve Bayes yang digunakan juga akan menggunakan skema pembagian data pada regresi logistik.

Hasil klasifikasi terhadap data training berdasarkan masingmasing metode akan menghasilkan klasifikasi sebagai berikut.

Tabel 11. Klasifikasi Daya Tanggap Menggunakan Nä̈ve Bayes

\begin{tabular}{|c|c|c|c|}
\hline & \multicolumn{3}{|c|}{ Penjualan Produk } \\
\hline & & Rendah & Tinggi \\
\hline \multirow[t]{3}{*}{ Daya Tanggap } & Rendah & 16 & 1 \\
\hline & Sedang & 17 & 13 \\
\hline & Tinggi & 4 & 35 \\
\hline
\end{tabular}

Tabel tersebut menunjukkan bahwa karyawan dengan daya tanggap tinggi memiliki penjualan produk yang tinggi sebanyak 35 orang, hal yang perlu diperhatikan adalah karyawan dengan daya tanggap sedang cenderung memiliki penjualan produk yang rendah sebanyak 17 orang, sehingga daya tanggap karyawan perlu ditingkatkan. Klasifikasi terhadap kreatifitas karyawan dapat dilihat pada hasil sebagai berikut.

Tabel 12. Klasifikasi Kreatifitas Menggunakan Nä̈ve Bayes

\begin{tabular}{llrr}
\multicolumn{4}{c}{ Penjualan Produk } \\
& Rendah & Tinggi \\
\hline \multirow{2}{*}{ Kreatifitas } & Rendah & 28 & 1 \\
& Sedang & 8 & 16 \\
& Tinggi & 1 & 32 \\
\hline
\end{tabular}

Kreatifitas karyawan perusahaan cenderung terbagi dalam dua kategori besar yaitu karyawan dengan kreatifitas rendah serta karyawan dengan kreatifitas tinggi.Karyawan dengan kreatifitas rendah cenderung mempengaruhi penjualan produk menjadi rendah, hal sebaliknya terlihat dari karyawan dengan kreatifitas tinggi yang turut meningkatkan penjualan produk.Klasifikasi terhadap motivasi dapat dilihat sebagai berikut.

Tabel 12. Klasifikasi Motivasi Menggunakan Nä̈ve Bayes

Penjualan Produk

\begin{tabular}{llrr} 
& & Rendah & Tinggi \\
\hline Motivasi & Rendah & 22 & 1 \\
& Sedang & 14 & 7 \\
& Tinggi & 1 & 41 \\
\hline
\end{tabular}

Motivasi karyawan terlihat cukup tinggi dengan 41 orang karyawan tergolong memiliki penjualan produk yang tinggi.Ketepatan dan kebaikan model klasifikasi menggunakan Nä̈ve Bayes dapat dilihat sebagai berikut.

Tabel 12. Hasil Ketepatan dan Kebaikan Model Menggunakan Nä̈ve Bayes

\begin{tabular}{|c|c|c|c|}
\hline Hasil Klasifikasi & $\begin{array}{l}\text { Skema } \\
90 \%\end{array}$ & $\begin{array}{l}\text { Skema } \\
80 \%\end{array}$ & $\begin{array}{l}\text { Skema } \\
70 \%\end{array}$ \\
\hline Correctly Classified Instance & $87,5 \%$ & $93,75 \%$ & $95,83 \%$ \\
\hline $\begin{array}{l}\text { Incorrectly Classified } \\
\text { Instance }\end{array}$ & $12,5 \%$ & $6,25 \%$ & $4,17 \%$ \\
\hline Kappa Statistics & 0,7143 & 0,875 & 0,9167 \\
\hline Root Mean Squared Error & 0,2762 & 0,2121 & 0,1624 \\
\hline
\end{tabular}

Tabel tersebut menunjukkan ketepatan model, kebaikan serta kemampuan model untuk mengklasifikasikan data testing sesuai model yang dibentuk oleh data training berdasarkan skema yang telah ditentukan. Model serta klasifikasi terbaik yang dapat dianjurkan untuk digunakan adalah model dengan Nä̈ve Bayes dengan skema 70\%. Saran diberikan berdasarkan ketepatan klasifikasi mencapai 95,83\%, RMSE yang cukup rendah sebesar 0,1624. Kebaikan model yang didasarkan nilai Kappa Statistics adalah sebesar 0,9167 atau mendekati nilai 1, sehingga dapat dikategorikan sangat baik untuk digunakan sebagai model.

\section{KESIMPULAN DAN SARAN}

\section{A. Kesimpulan}

Berdasarkan hasil analisis dan pembahasan yang dipaparkan pada bab sebelumnya, dapat diambil beberapa kesimpulan sebagai berikut.

1. Pengklasifikasian dengan menggunakan metode Regresi Logistik menghasilkan ketepatan klasifikasi terbaik sebesar 95,83\%, dengan RMSE 0,2041 serta kebaikan model untuk digunakan sebagai dasar klasifikasi sebesar 0,9167. Daya Tanggap Rendah dan Motivasi yang Rendah menjadi titik pengamatan utama karena berdasarkan Regresi Logistik mempengaruhi penurunan penjualan produk dan perlu ditingkatkan.

2. Pengklasifian dengan metode Naïve Bayes menghasilkan ketepatan klasifikasi sebesar 95,83\% dengan RMSE sebesar 0,1624 dan kebaikan model mencapai 0,9167 atau berada pada kategori cukup baik untuk dilakukan pemodelan klasifikasi.

3. Perbandingan ketepatan klasifikasi dan kebaikan model menunjukkan bahwa Regresi Logistik dan Nä̈ve Bayes menghasilkan model yang sama baiknya dengan skema terbaik adalah data training $70 \%$ dan data testing $30 \%$. 
Perbandingan jika dilihat menggunakan RMSE cenderung menunjukkan Nä̈ve Bayes dengan skema $70 \%$ merupakan model yang disarankan dengan RMSE yang cenderung rendah dibanding skema dan metode lain.

\section{B. Saran}

Untuk penelitian selanjutnya disarankan untuk menambah jumlah variabel penelitian yang berhubungan dengan kinerja karyawan PT. Gunung Meranti..Selain itu, disarankan juga untuk mengambil sampel dengan jumlah yang lebih banyak karena dengan data yang lebih banyak maka mampu dilakukan klasifikasi serta kategori lebih baik terhadap karyawan PT. Gunung Meranti.

\section{DAFTAR PUSTAKA}

[1] R. A. Subektianto, M. Ratna and I. Zain, "Analisis Kepuasan Pasien dan Pelaksana Terhadap Sistem Informasi Manajemen Puskesmas Elektronik (Simpustronik) di Kabupaten Blitar Menggunakan Regresi Logistik Biner," Inferensi, vol. 1, no. 1, pp. 29-37, 2018.

[2] A. Agresti, Categorical Data Analysis, New Jersey: John Wiley \& Sons, 2002.

[3] D. W. Hosmer and S. Lemeshow, Applied Logistic Regression, New York: John Wiley and Sons.Inc, 1995. 